\title{
ANALISIS PERTUMBUHAN POPULASI CACING SUTERA (Tubifex $s p$ ) SEBAGAI SUMBER PAKAN ALAMI IKAN
}

\author{
Novita Hamron ${ }^{1)}$, Yar Johan ${ }^{2)}$, Bieng Brata ${ }^{3)}$ \\ ${ }^{1)}$ Universitas Ratu Samban Arga Makmur \\ ${ }^{2)}$ Program Studi Ilmu Kelautan Fakultas Pertanian UNIB \\ 3) Jurusan Peternakan Fakultas Pertanian UNIB
}

\begin{abstract}
ABSTRAK
Cacing Sutera (Tubifex sp) merupakan pakan alami yang kebutuhannya sangat penting dalam budidaya perikanan terutama pada pemeliharaan larva dan benih ikan. Permintaan Pakan alami Cacing Sutera (Tubifex sp) semakin meningkat pesat, harga Cacing Sutera (Tubifex sp) yang sangat mahal tentunya dapat menjadi prospek dimasa depan. Penelitian ini bertujuan untuk mengetahui dan memperoleh komposisi media pemeliharaan yang terbaik guna meningkatkan pertumbuhan populasi Cacing Sutera (Tubifex $s p$ ) dengan melalui upaya pemanfaatan limbah-limbah organik agar pemanfaatannya lebih optimal. Penelitian ini menggunakan Metode Rancangan Acak Lengkap (RAL) dengan 3 perlakuan dan 6 kali ulangan ketiga perlakuan tersebut yaitu Perlakuan A (Ampas Tahu), B (Tepung udang), dan $\mathrm{C}$ (Tepung dedak). Data hasil penelitian di analisis dengan menggunakan sidik ragam Anova dan uji lanjut Duncan Multiple Range Test (DMRT) untuk melihat perbedaan perlakuan. Hasil penelitian menunjukkan bahwa biomassa tertinggi pada perlakuan B (Tepung Udang) dengan pertumbuhan bobot Cacing Sutera (Tubifex sp) sebesar 503,99 gram dan di ikuti oleh perlakuan $\mathrm{C}$ (Tepung dedak) dengan rata-rata biomassa sebesar 414,45 gram dan terendah pada perlakuan A (Ampas tahu) dengan rata-rata biomassa sebesar 309,41 gram.
\end{abstract}

Kata Kunci: Cacing Sutera (Tubifex Sp), Sumber Protein, Pakan Ikan

\section{PENDAHULUAN}

Cacing Sutera (Tubifex sp) merupakan pakan alami yang kebutuhannya sangat penting dalam budidaya perikanan terutama pada pemeliharaan larva dan benih. Permintaan pakan alami Cacing Sutera (Tubifex sp) semakin meningkat pesat, harga Cacing Sutera (Tubifex sp) yang sangat mahal tentunya dapat menjadi prospek dimasa depan. Di lihat dari segi bentuknya yang menggelikan dan menjijikkan Cacing Sutera (Tubifex sp) disukai oleh benih ikan khususnya ikan air tawar, begitu pula dengan ikan hias dan udang juga sangat menyukai Cacing Sutera (Tubifex $s p$ ). Adapun jenis-jenis ikan hias yang biasa mengkonsumsi cacing tubifex yaitu ikan koki, platy, diskus, maanvis, cupang, guppy dan masih banyak lagi jenis ikan hias lainnya. Untuk ikan konsumsi yang masih berukuran benih seperti ikan lele, nila, karper, gurami, juga sangat menggemari Cacing Sutera (Tubifex sp).

Tingkat mortalitas merupakan masalah yang merugikan dalam budidaya, untuk mempercepat proses pertumbuhan benih ikan sebaiknya harus diberikan pakan tambahan berupa Cacing Sutera (Tubifex $s p$ ) karena dalam hal pengadaan pakan tidak cukup hanya mengandalkan kuning telur saja dengan pemberian Cacing Sutera (Tubifex sp) merupakan salah satu terbaik pakan alternatif untuk tumbuh kembang larva dan benih ikan. Cacing Sutera (tubi$f e x s p$ ) mudah disantap oleh larva dan be- 
nih karena ukurannya yang kecil dan sesuai dengan ukuran mulut larva dan benih ikan. Pemberian pakan buatan yang dikombinasikan dengan Cacing Sutera (Tubifek $s p$ ) diharapkan dapat menjadi solusi untuk meningkatkan pertumbuhan dan menurunkan angka mortalitas pada larva/benih ikan.

Habitat dan penyebaran Cacing sutera (Tubifex $s p$ ) ditemukan di daerah tropis. Dasar perairan yang di sukai cacing ini adalah berlumpur dan mengandung bahan organik, karena bahan-bahan organik yang telah terurai dan mengendap didasar perairan merupakan makanan utamanya. Cacing Sutera (Tubifex sp) akan membenamkan kepalanya kedalam lumpur untuk mencari makanan. Sementera itu ujung ekornya akan di sembulkan diatas permukaan lumpur untuk bernapas. Umumnya Cacing Sutera bisa hidup di substrat lumpur dengan kedalaman 0-4 cm (Effendi, 2017)

Media kultur sebagai tempat pemeliharaan Cacing Sutera sangatlah penting, hal ini sangat berpengaruh terhadap pertumbuhan dan kandungan nutrisi dari Cacing Sutera (Tubifex $s p$ ) Nutrient yang tinggi terutama kandungan $\mathrm{N}$ dan $\mathrm{P}$ didalam pupuk organik tersebut dapat dimanfaatkan untuk memacu pertumbuhan dan peningkatan kualitas nutrisi yang terkandung dalam Cacing Sutera (Tubifex $s p)$.

Menurut Yuherman (1987), kombinasi kotoran ayam dan lumpur halus masingmasing sebanyak $50 \%$ sebagai substrat budidaya Cacing Sutera (Tubifex sp) terbukti menghasilkan populasi yang tinggi dan mencapai puncak pada hari ke- 40 . Penambahan kotoran burung puyuh pada media kotoran ayam karena memiliki kandungan organik $\mathrm{N}, \mathrm{P}$ dan $\mathrm{K}$ yang cukup tinggi dengan melalui pengelolaan fermentasi dapat digunakan sebagai media tumbuh cacing Sutera (Tubifex $s p$ ) Menurut Huri dan Syafriadiman, (2007) dalam Syahendra, (2016) pupuk kotoran puyuh memiliki kandungan protein sebesar
$21,00 \%$ dan kandungan nitrogen sebesar $0,06 \%$.

Ampas tahu, limbah udang dan dedak merupakan limbah yang dapat dipergunakan sebagai pakan tambahan pada pemeliharaan Cacing Sutera (Tubifex sp) ampas tahu dan limbah udang memiliki kandungan protein yang cukup tinggi untuk meningkatkan pertumbuhan Cacing Sutera (Tubifex sp) terutama ampas tahu, limbah udang dan dedak bisa dijadikan alternatif pakan tambahan pada budidaya Cacing Sutera (Tubifex sp) selain itu limbah tersebut murah dan mudah didapatkan terkhusus di wilayah Bengkulu.

Salah satu hewan ternak tergolong unggas yang cukup berpotensi sebagai penghasil kompos dan organik pada kegiatan Media pemeliharaan Cacing Sutera adalah Burung puyuh yang diternakkan secara massal. Dengan semakin meningkatnya peternakan burung puyuh semakin meningkat pula limbah kotoran puyuh yang dihasilkan tentunya kotoran puyuh juga berpotensi apa lagi di dukung dengan daerah sentra peternakan dan sentra perikanan air tawar, budidaya ikan hias dan udang di Provinsi Bengkulu, diperlukan kombinasi-kombinasi media tumbuh secara sinergi dan integrasi sehingga kotoran yang bersumber dari peternakan $\mathrm{Bu}$ rung Puyuh dapat dimanfaatkan pula sebagai media pemeliharaan Cacing Sutera (Tubifex sp). Cacing Sutera sebagai pakan alami dan pakan alternatif tambahan pada pemeliharaan larva/benih ikan air tawar dan hias maupun udang. Selain itu belum adanya pencapaian hasil kegiatan budidaya yang optimal yang dilakukan oleh masyarakat pada pemanfaatan media limbah kotoran ternak.

Berdasarkan pertimbangan tersebut, perlu dilakukan upaya pengkajian atau riset dan pengembangan teknologi dalam budidaya Cacing Sutera (Tubifex $s p$ ) melalui penelitian ini akan di coba jenis media tumbuh yang berasal dari limbah organik kotoran burung puyuh yang dikombinasi kotoran ayam dengan menggunakan 
tiga pakan tambahan ampas tahu, tepung limbah udang dan dedak (hasil fermentasi) menggunakan EM-4 dan ragi tapai yang tujuannya untuk mencari tahu jenis media tumbuh yang manakah yang efektif dalam meningkatkan pertumbuhan populasi Cacing Sutera (Tubifex sp) dengan memanfaatkan limbah-limbah dari kotoran hewan unggas sehingga limbah organik yang terus meningkat dapat dimanfaatkan secara optimal.

\section{METODE PENELITIAN}

\section{Waktu dan Tempat Penelitian}

Penelitian ini dilakukan pada bulan Februari sampai dengan Maret 2018, dilokasi kolam pembesaran dan pembenihan Lele sangkuriang di Bumi ayu, Kotamadya Bengkulu.

\section{Alat dan Bahan Penelitian}

Alat yang digunakan dalam penelitian adalah : Nampan, Talang air, Paralon PVC, Paralon L PVC, Paralon besar, Pipa listrik, Paranet, Papan, Dolken, reng, Palstik hitam, Baskom besar, ember besar, bok besar, Timbangan digital, Mesin Aquila P 1800, Grundfos $350 \mathrm{~A}$, Thermometer, DO meter, kertas $\mathrm{pH}$ indikator, kamera, Saringan, Plastik, Scopnet. Sedangkan Bahan yang digunakan pada penelitian ini adalah : Hewan Cacing Sutera 500 gram, Lumpur kolam, kotoran puyuh $50 \mathrm{~kg}$, kotoran ayam, ampas tahu, tepung limbah udang, dan dedak, Larutan EM4 $50 \mathrm{ml}$, Ragi tapai 6 buah.

\section{Rancangan Percobaan}

Metode Penelitian ini menggunakan Metode eksperimental Rancangan Acak Lengkap (RAL) dengan 3 perlakuan dan 6 kali ulangan adapun ketiga perlakuan tersebut adalah : 1). Perlakuan A: Lumpur 20\% + Kotoran Puyuh 30\% + KotoranAyam $30 \%$ + Ampas tahu 20\%,
2). Perlakuan B : Lumpur $20 \%+$ Kotoran Puyuh 30\% + Kotoran Ayam $30 \%+$ Tepung limbah udang 20\%, 3). Perlakuan C : Lumpur 20\% + Kotoran Puyuh 30\% + Kotoran Ayam 30\% + Tepung dedak $20 \%$.

Tiga perlakuan tersebut diulang sebanyak 6 kali sehingga terdapat 18 unit satuan percobaan. Parameter utama yang akan diteliti meliputi populasi Biomassa Cacing Sutera (Tubifex sp). Pemanenan di lakukan setelah 40 hari masa pemeliharaan Cacing Sutera (Tubifex sp).

\section{Analisis Data \\ Analisis Parameter Lingkungan Media Cacing Sutera}

Pengukuran parameter kualitas lingkungan media kultur Cacing Sutera (Tubifex $s p$ ) yang diutamakan adanya parameter penunjang yaitu suhu, DO, $\mathrm{pH}$ dimedia kultur yang dilakukan setiap hari untuk mengetahui rata-rata, suhu, $\mathrm{DO}, \mathrm{pH}$ pada awal, tengah dan akhir penelitian. Metode pengukuran kualitas air berdasarkan pada APHA (2005).

\section{Pertumbuhan Mutlak Biomassa Cacing Sutera (Tubifex sp)}

Menurut Penelitian Weatherley (1972) rumus untuk mencari pertumbuhan mutlak yaitu sebagai berikut :

$\mathbf{W}=\mathbf{W t}-\mathbf{W o}$

Keterangan :

$\mathrm{W}$ :Pertumbuhan mutlak (gram)

Wt :Biomassa pada waktu (t) (gram)

Wo:Biomassa pada awal penelitian (gram)

Perhitungan pertumbuhan mutlak bobot biomassa Cacing Sutera (Tubifex $s p$ ). Cacing Sutera (Tubifex sp) pada awal penebaran ditimbang untuk mengetahui bobot biomassa awal penebaran. Kemudian setelah pada akhir penelitian dilakukan pemanenan total Cacing Sutera (Tubifex $s p$ ) lalu ditimbang untuk mengetahui bobot 
dan pertumbuhan biomassa akhir Cacing Sutera (Tubifex sp).

\section{Analisis Sidik Ragam}

Analisis Data untuk mengetahui pengaruh perlakuan yang dicobakan data hasil pengamatan pertumbuhan mutlak Cacing Sutera (Tubifex sp) dianalisis dengan sidik ragam (Gomes, 1995).

$$
Y \mathbf{i j}=\boldsymbol{\mu}+\mathbf{t i}+\varepsilon \mathbf{i j}
$$

Keterangan :

\begin{tabular}{|c|c|}
\hline Yij & : Hasil pengamatan pada \\
\hline & perlakuan ke-i dan ulangan ke-j \\
\hline$\mu$ & : Nilai tengah data \\
\hline ti & : Pengaruh perlakuan ke-i ( $\left(\begin{array}{lll}1 & 2 & 3\end{array}\right)$ \\
\hline & $\begin{array}{l}\text { :Kesalahan percobaan pada } \\
\text { perlakuan ke-i dan ulangan ke-j }\end{array}$ \\
\hline
\end{tabular}

Data yang di peroleh dari kegiatan penelitian ini di analisis dengan menggunakan sidik ragam Anova (Analisis Of Variance) dan dilanjutkan dengan Uji lanjut Duncan Multiple Range Test (DMRT) untuk melihat perbedaan perlakuan.

\section{HASIL DAN PEMBAHASAN}

Analisis C Organik dan N Organik Media Tumbuh Cacing Sutera (Tubifex sp)

Berdasarkan hasil uji laboratorium kandungan bahan organik media kultur Cacing Sutera (Tubifex sp) dapat dilihat pada Tabel 1.

Tabel 1. Hasil analisis kandungan hara media kultur Cacing Sutera (Tubifex $s p$ )

\begin{tabular}{lccc}
\hline Perlakuan & $\mathrm{C}$ & $\mathrm{N}$ & Rasio \\
& Organik & Organik & $\mathrm{C} / \mathrm{N}$ \\
\hline A (Ampas tahu) & 6,3 & 1,17 & 5,38 \\
B (Tepung udang) & 4,79 & 0,89 & 5,38 \\
C (Tepung dedak) & 7,47 & 0,76 & 9,87 \\
\hline
\end{tabular}

Berdasarkan hasil analisis kandungan hara media kultur Cacing Sutera (Tubifex $s p)$ pada Tabel $1 \mathrm{~N}$ organik tertinggi pada perlakuan A (Ampas tahu) $1,17 \%$, pada perlakuan B (Tepung udang) $0,89 \%$ dan terendah pada perlakuan $\mathrm{C}$ (Tepung dedak) $0,76 \%$. Sedangkan $C$ organik tertinggi pada perlakuan $\mathrm{C}$ (Tepung dedak) $7,47 \%$, pada perlakuan A (Ampas tahu) sebesar 6,30\% dan pada perlakuan B (Tepung udang) $4,79 \%$. Sedangkan kandungan $\mathrm{C} / \mathrm{N}$ rasio tertinggi pada perlakuan $\mathrm{C}$ (Tepung dedak) sebesar 9,87\% kemudian terendah pada perlakuan B (Tepung udang) 5,38\% dan pada perlakuan A (Ampas tahu) sebesar 5,38\%.

Mengapa pada perlakuan B (Tepung udang), $\mathrm{N}$ organik dan $\mathrm{C} / \mathrm{N}$ rasionya rendah karena pada media tumbuh Cacing Sutera (Tubifex $s p$ ) pada perlakuan B
(Tepung udang) memiliki kandungan tepung limbah udang dan kandungan protein yang tinggi, mengapa demikian karena adanya. Aspergillus niger adalah kapang anggota genus aspergillus, yang menghasilkan beberapa enzim ekstra seluler diantaranya amilase, glukoamilase, selulase, hemiselulase, pektinase, glulosidase, yang berperan sebagai pemecah karbohidrat, dan protease sebagai pemecah protein. Enzim protease dapat digunakan untuk memisahkan nitrogen $(\mathrm{N})$ pada ikatan khitin cangkang udang (Hardjo, et al., 1989 dalam Rorsyidi et al., 2009). Rendahnya C/N rasio pada perlakuan B (Tepung udang) tidak mempengaruhi berkurangnya populasi Cacing Sutera (Tubifex sp) diperkirakan adanya faktor lain yang berasal dari tepung udang dan pakan tambahan kombinasi 
yang sudah difermentasi yang menjadikan cacing berkembang sangat tinggi pada perlakuan B (Tepung udang).

\section{Analisis Parameter Lingkungan}

Hasil pengamatan selama 40 hari terhadap kualitas lingkungan yang terdiri dari suhu, $\mathrm{pH}$ dan DO terhadap media pemeliharaan Cacing Sutera (Tubifex $s p$ ) dalam wadah berupa nampan pada masingmasing perlakuan. Adapun perubahan suhu selama masa pemeliharaan Cacing Sutera (Tubifex sp) dapat dilihat dalam bentuk Grafik sebagai berikut.

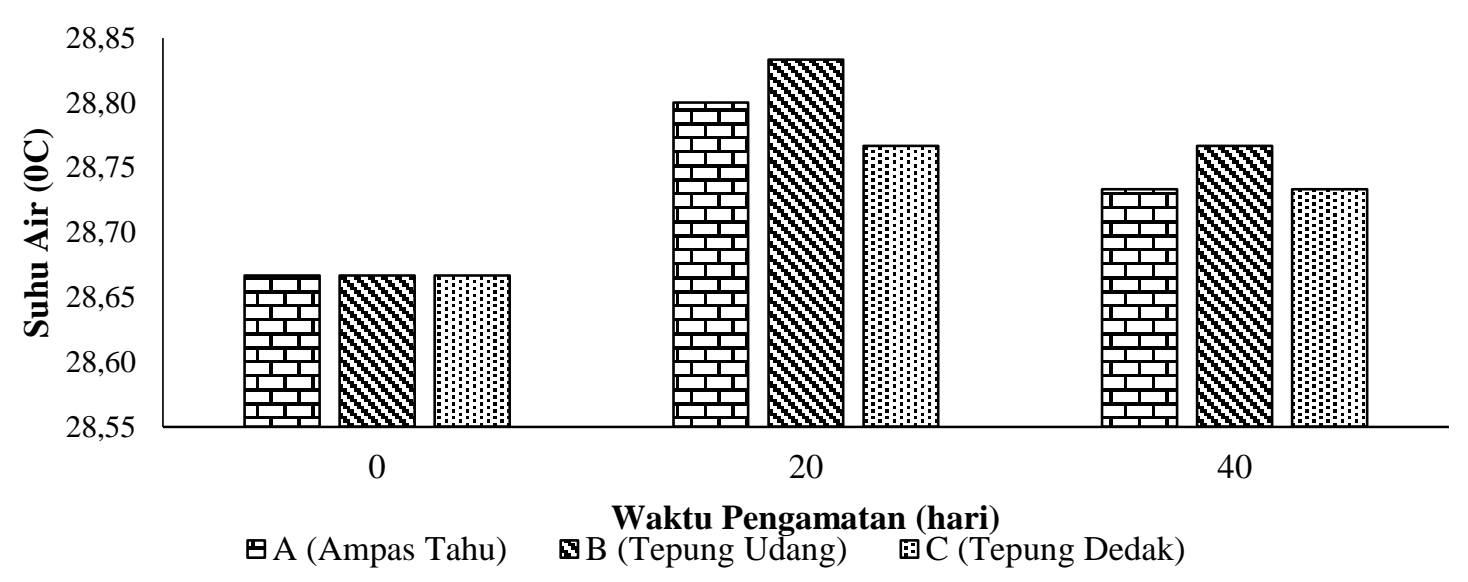

Gambar 1. Grafik rata-rata suhu air selama penelitian

Berdasarkan Grafik pada Gambar1 dapat dilihat nilai kisaran rata-rata suhu air selama penelitian. suhu pada awal penelitian memperlihatkan nilai yang sama pada ketiga perlakuan baik perlakuan $\mathrm{A}$ (Ampas tahu) sekitar $28,67^{\circ} \mathrm{C}$, perlakuan B (Tepung udang) sekitar $28,67^{\circ} \mathrm{C}$ dan disusul perlakuan $\mathrm{C}$ (Tepung dedak) sekitar $28,67^{\circ} \mathrm{C}$. Pada hari ke 20 mengalami peningkatan suhu dengan menunjukkan rata-rata suhu media kultur tertinggi pada perlakuan B (Tepung udang) sekitar $28,83^{\circ} \mathrm{C}$ dan perlakuan A (Ampas tahu) sekitar $28,80^{\circ} \mathrm{C}$, kemudian di susul perlakuan $\mathrm{C}$ (Tepung dedak) sekitar $28,77^{\circ} \mathrm{C}$. Sedangkan pada pemeliharaan hari ke 40 diakhir penelitian suhu mengalami penurunan yaitu pada perlakuan B (Tepung udang) sekitar $28,77^{\circ} \mathrm{C}$, pada perlakuan A (Ampas tahu) $28,73^{\circ} \mathrm{C}$ dan di ikuti perlakuan $\mathrm{C}$ (Tepung dedak) sekitar $28,73^{\circ} \mathrm{C}$. Pada masa pemeliharaan Cacing Sutera (Tubifex sp) selama 40 hari terjadi naik turunnya suhu yang disebabkan oleh pengaruh suhu lingkungan hal ini diduga penempatan wadah media pemeliharaan berada diluar ruangan terbuka (dialam terbuka) sehingga sering menimbulkan naik turunnya suhu air media pemeliharaan yang disebabkan oleh panas dan hujan. Sehubungan dengan hal itu daerah bumi ayu yang berada beberapa kilometer dari garis pantai dengan melihat nilai dari suhu tersebut layak dan memenuhi syarat untuk budidaya Cacing Sutera (Tubifex $s p$ ) sesuai dengan pernyataan Adlan (2014) parameter kelayakan suhu media pemeliharaan Cacing Sutera (Tubifex sp) yaitu berkisar antara $24-32^{\circ} \mathrm{C}$.

Kualitas air adalah parameter sebagai media pendukung pertumbuhan Cacing Sutera (Tubifex $s p$ ) juga pemacu kecepatan pertumbuhan dan populasi Cacing Sutera (Tubifex sp), kesesuaian tersebut sama dengan pendapat Hadiroseyani et al. 
(2007) mengatakan bahwa kisaran suhu air yang sesuai untuk kultur Cacing Sutera (Tubifex sp) berkisar antara $25-30^{\circ} \mathrm{C}$.
Adapun perubahan derajat keasaman $(\mathrm{pH})$ air selama penelitian dapat dilihat pada Gambar 2.

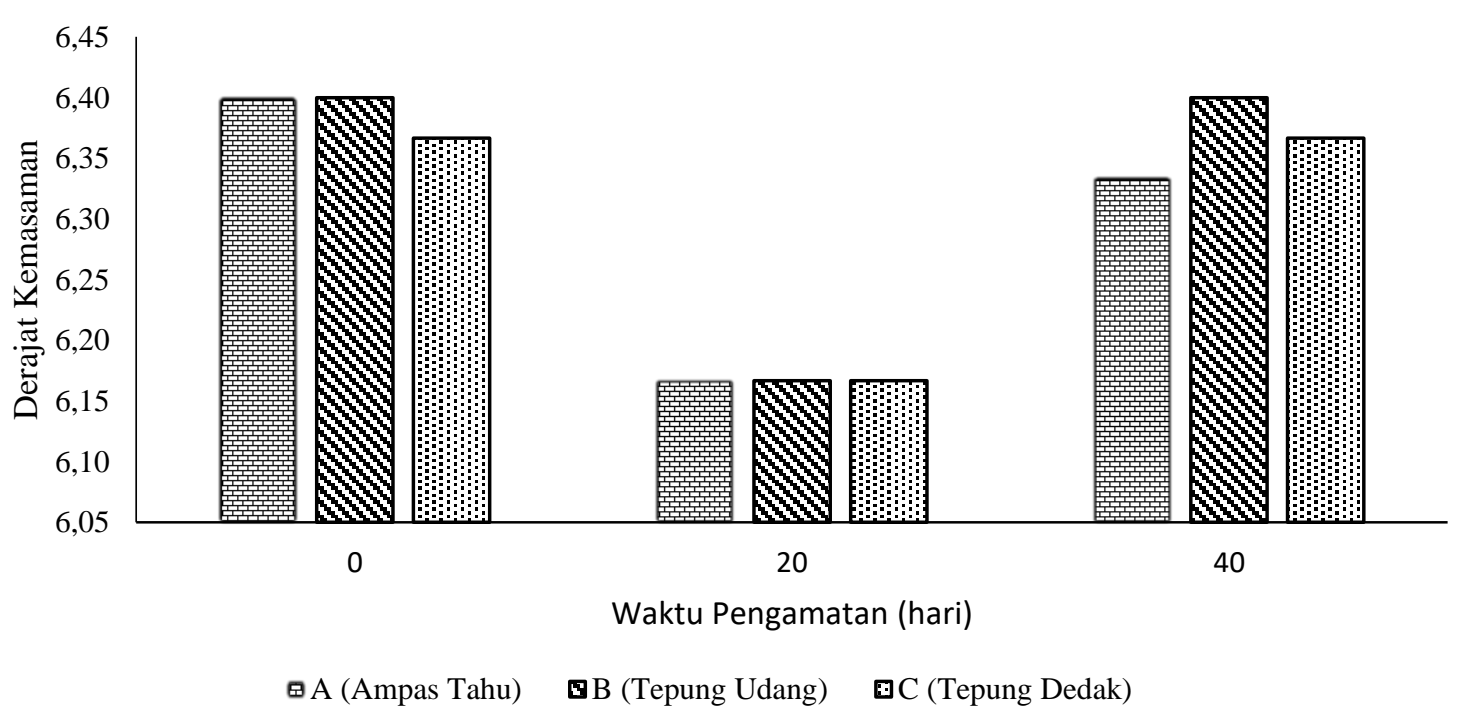

Gambar 2. Grafik rata-rata pH air selama penelitian

Berdasarkan Grafik Pada Gambar 2 dapat dilihat nilai rata-rata hasil pengukuran derajat keasaman $\mathrm{pH}$ air media tumbuh Cacing Sutera (Tubifex $s p$ ) selama pemeliharan dengan kisaran $\mathrm{pH}$ awal penelitian pada perlakuan A (Ampas tahu) sekitar 6,40, perlakuan B (Tepung udang) sekitar 6,40 dan perlakuan C (Tepung dedak) sekitar 6,37. Pada hari ke $20 \mathrm{pH}$ sedikit mengalami kenaikan dengan rata-rata nilai $\mathrm{pH}$ sama pada perlakuan $\mathrm{A}$ (Ampas tahu) 6,17, pada perlakuan B (Tepung udang) sekitar 6,17 dan pada perlakuan C (Tepung dedak) sekitar 6,17. Sedangkan pada hari ke 40 mengalami peningkatan $\mathrm{pH}$, tertinggi pada perlakuan B (Tepung udang) 6,40, di ikuti perlakuan C (Tepung dedak) 6,37 dan disusul perlakuan A (Ampas tahu) 6,33. Rata-rata pH tertinggi pada perlakuan B (Tepung udang) yang berkisar 6,17-6,40 dan sama tinggi pada perlakuan $\mathrm{C}$ (Tepung dedak) 6,17-6,37 dan terendah pada perlakuan A (Tepung dedak) 6,17-6,33. Tingginya $\mathrm{pH}$ pada hari ke 40 pada perlakuan B (Tepung udang) dan di ikuti perlakuan $\mathrm{C}$ (Tepung dedak) diduga pada media organik mengalami proses pembusukan atau oksidasi secara merata dan itu dampak dari proses fermentasi selama 10 hari jadi $\mathrm{pH}$ pada perlakuan B (Tepung udang) sangat layak, jadi nilai kadar $\mathrm{pH}$ tersebut layak untuk pemeliharaan Cacing Sutera (Tubifex $s p$ ) pernyataan tersebut senada dengan yang disampaikan Efendi (2013) bahwa kisaran $\mathrm{pH}$ yang optimal untuk budidaya cacing sutera adalah 5,5-8,0. Sedangkan untuk kisaran $\mathrm{pH}$ media kultur Menurut Shafrudin, (2005) bahwa kisaran $\mathrm{pH}$ 6,02-7,7 merupakan kisaran $\mathrm{pH}$ optimal untuk kelangsungan hidup Cacing Sutera (Tubifex sp).

Sedangkan $\mathrm{pH}$ pada perlakuan $\mathrm{C}$ (Tepung dedak) dan A (Ampas tahu) juga tergolong masih dalam kisaran layak namun populasi cacing tetap rendah dibandingkan perlakuan B (Tepung udang) yang membuat rendahnya populasi cacing pada perlakuan $\mathrm{C}$ (Tepung dedak) dan $\mathrm{A}$ (Ampas tahu) hal tersebut diduga adanya faktor lain yaitu tingginya kandungan karbohidrat yang terdapat didalam media 
pemeliharaan yang berasal dari dedak. Seperti pernyataan Suharyadi (2012) tingkat keasaman $\mathrm{pH}$ banyak dipengaruhi oleh beberapa faktor pembentukannya antara lain bahan organik, $\mathrm{pH}$ tanah dasar dan $\mathrm{pH}$ air yang rendah diikuti dengan kandungan bahan organik yang terakumulasi dan tidak terjadi oksidasi yang sempurna.

Rata-rata Oksigen Terlarut (DO) terlarut selama penelitian dapat dilihat dalam bentuk Grafik pada Gambar 3. Pada awal penelitian di dapat nilai DO pada perlakuan B (Tepung udang) sekitarr 4,87 ppm, pada perlakuan $\mathrm{C}$ (Tepung dedak) sekitar 4,83 ppm dan di susul perlakuan A
(Ampas tahu) sekitar 4,73 ppm. Pada hari ke 20 nilai oksigen terlarut (DO) mengalami peningkatan dan menghasilkan nilai tertinggi pada perlakuan B (Tepung udang) 5,03 ppm kemudian di ikuti perlakuan A (Ampas tahu) sekitar 4,97 ppm sedangkan pada perlakuan C (Tepung dedak) sekitar 4,83 ppm. Sedangkan pada hari ke 40 ketiga perlakuan mengalami penurunan DO pada perlakuan B (Tepung udang) sekitar 4,90 ppm dan di susul oleh perlakuan A (Ampas tahu) sekitar 4,87 ppm dan terendah pada perlakuan $\mathrm{C}$ (Tepung dedak) sekitar 4,77 ppm.

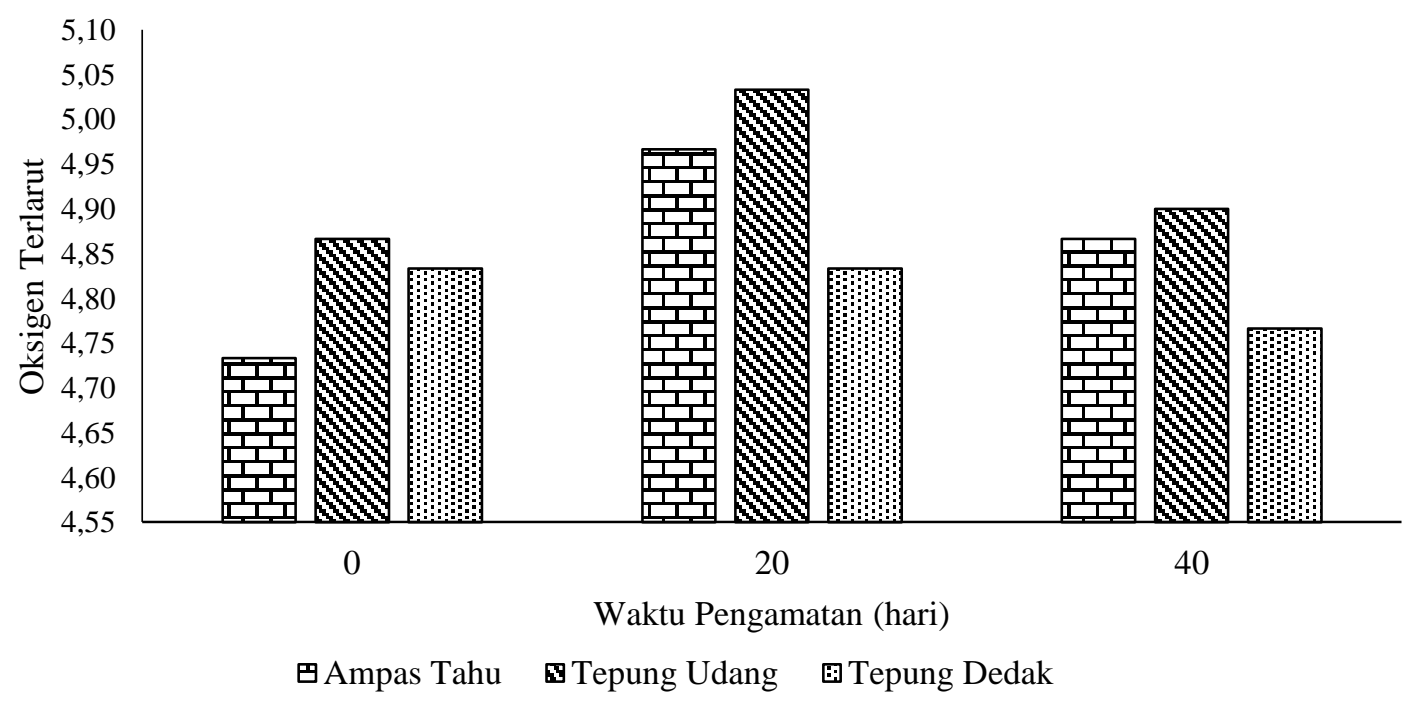

Gambar 3. Grafik rata-rata oksigen terlarut (DO) selama penelitian

Kisaran DO selama penelitian tersebut menunjukkan angka-angka yang cukup layak untuk kelangsungan hidup Cacing Sutera (Tubifex $s p$ ) terutama pada perlakuan B (Tepung udang) rata-rata nilai oksigen terlarut berkisar 4,87-5,03 ppm, dari hasil penelitian tersebut DO media pemeliharaan sangat layak untuk mengembangbiakan Cacing Sutera (Tubifex sp) dimana Cacing Sutera (Tubifex sp) mengalami peningkatan pertumbuhan dan berkembangbiak secara merata, itupun senada pula dengan apa yang dikatakan Efendi (2013) menyatakan bahwa kisaran kelayakan DO untuk tumbuh kembang biak cacing sutera (Tubifex sp) yaitu 2,5-7 ppm. Sama hal nya juga pendapat Febrianti (2004) kelayakan parameter kualitas lingkungan pada DO untuk media hidup Cacing Sutera (Tubifex $s p$ ) adalah berkisar antara 0,42-6,96 ppm. 
Semua organisme yang hidup sangat membutuhkan DO yaitu oksigen terlarut untuk bernapas, dan bermetabolisme agar dapat melakukan pertukaran zat-zat sehingga menghasilkan semacam energi untuk meningkatkan pertumbuhan dan berkembang biak. Menurut Salmin, (2000) mengatakan bahwa oksigen sangat dibutuhkan bahan-bahan organik dan anorganik untuk beroksidasi dalam proses aerobik.

\section{Analisa biomassa Cacing Sutera (Tubifex sp)}

Hasil pengamatan pertumbuhan bobot mutlak biomassa cacing Sutera (Tubifex $s p)$ rata-rata biomassa tertinggi terdapat pada perlakuan B (Tepung udang) dengan pertumbuhan rata-rata biomassa 503,99 gram diikuti dengan perlakuan $\mathrm{C}$ (Tepung dedak) dengan rata-rata biomassa 414,45 gram. Sedangkan biomassa terendah terdapat pada perlakuan A (Ampas tahu) dengan rata-rata biomassa sebesar 309,41 gram.

Hasil analisis sidik ragam Anova pengaruh perlakuan terhadap pertumbuhan bobot mutlak Cacing Sutera (Tubifex sp) dapat dilihat pada Tabel 4.3 menunjukkan bahwa hasil ketiga perlakuan berpengaruh sangat nyata pada pemberian komposisi media pemeliharaan yang berbeda terhadap pertumbuhan bobot mutlak Cacing Sutera (Tubifex $s p$ ) yaitu $(\mathrm{P}<0,05)$.

Tabel 2. Hasil Analisis sidik ragam pertumbuhan bobot mutlak Cacing Sutera

\begin{tabular}{lccccc}
\hline \multicolumn{1}{c}{ SK } & Db & JK & KT & F-hit & F-tabel \\
\hline Perlakuan & 2 & 113828.4775 & 56914.239 & $79,048183^{* *}$ & 3,68 \\
Galat & 15 & 10799.9141 & 719.99427 & & \\
Total & 17 & 124628.3916 & & & \\
\hline
\end{tabular}

$\mathrm{KK}=6.5560051 \%$

Ket:** = Berpengaruh sangat nyata

Hasil uji lanjut Duncan pengamatan mutlak Cacing Sutera (Tubifex sp) selama pemeliharaan dapat dilihat sebagai berikut. pertumbuhan bobot dan pertumbuhan

Tabel 3. Hasil uji lanjut DMRT pengaruh perlakuan terhadap pertumbuhan bobot mutlak Cacing Sutera (Tubifex sp).

\begin{tabular}{ll}
\hline Perlakuan & Pertumbuhan bobot Mutlak \\
\hline A (Ampas tahu) & $309,41 \mathrm{c}$ \\
B (Tepung Udang) & $503,99 \mathrm{a}$ \\
C (Tepung dedak) & $414,45 \mathrm{~b}$ \\
\hline
\end{tabular}

Keterangan : Angka-angka yang diikuti huruf yang berbeda pada kolom yang sama berbeda nyata pada uji DMRT

Berdasarkan Tabel 3. hasil uji lanjut Duncan pada pengamatan pertumbuhan bobot mutlak Cacing Sutera (Tubifex sp) menunjukkan bahwa nilai tertinggi pertumbuhan mutlak Cacing Sutera (Tubifex sp) ditemukan pada perlakuan B (Tepung udang), hal ini memberikan pengaruh yang berbeda sangat nyata $\mathrm{P}<0,05$ pada perlakuan A (Ampas tahu), B (Tepung udang), dan $\mathrm{C}$ (Tepung dedak) terhadap 
pertumbuhan bobot biomassa Cacing Sutera (Tubifex sp).

Pada Gambar 4 memperlihatkan nilai rata-rata pengaruh perlakuan terhadap pertumbuhan bobot mutlak biomassa Cacing Sutera (Tubifex $s p$ ) berbeda sangat nyata pada perlakuan B
(Tepung udang) memberikan pertumbuhan mutlak menunjukkan sangat berpengaruh nyata pada media pemeliharaan $20 \%$ lumpur $30 \%$ kotoran puyuh 30\% kotoran ayam dan 20\% tepung limbah udang menghasilkan nilai tertinggi sebesar 503,99 gram.

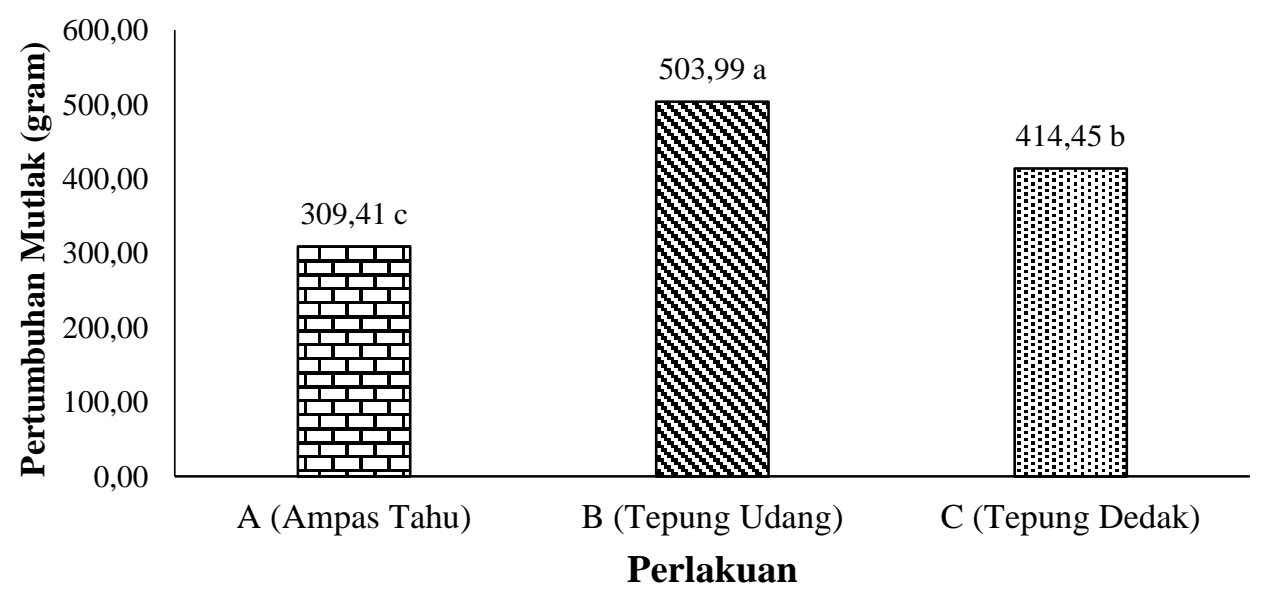

\section{Gambar 4. Grafik nilai pengaruh perlakuan terhadap pertumbuhan dan bobot mutlak}

Berdasarkan hasil analisis, mengapa pada perlakuan B (Tepung udang) pertumbuhan populasi Cacing Sutera (Tubifex $s p$ ) lebih tinggi sementara kandungan $\mathrm{N}$ organiknya rendah dan $\mathrm{C}$ organiknya lebih rendah dibanding perlakuan A (Ampas tahu) dan C (Tepung dedak) Tabel 4. Faktor Proses dekomposisi pada saat fermentasi merubah kandungan $\mathrm{N}$ organik turun $0,85 \%$ dan $\mathrm{C}$ organikpun ikut turun menjadi $4,79 \%$ dan ini disebabkan dari Limbah udang hasil fermentasi dapat mengubah bahan organik kompleks seperti protein, karbohidrat, dan lemak menjadi molekul-molekul yang lebih sederhana dan mudah dicerna, mengubah rasa dan aroma yang tidak disukai menjadi disukai, mempercepat pematangan, dan dalam beberapa hal tertentu menambah daya tahan (Rusdi, 1992). Selain mendapatkan pertumbuhan yang tertinggi Cacing Sutera (Tubifex $s p$ ) pada perlakuan B (Tepung udang), memiliki warna yang sangat merah mengkilat hal ini disebabkan karena adanya kandungan karoten jenis Xantofil yang terdapat pada tepung udang, dalam limbah udang mengandung karotinoid berupa astaxantin yang merupakan pro vitamin A untuk pembentukan warna kulit. Sumber pigmen yang baik adalah pakan yang mengandung xantofil. Jenis bahan baku pakan yang diketahui banyak mengandung xantofil adalah udang rebon (tepung udang) (Afrianto dan Liviawaty, 2005).

Rendahnya biomassa pada perlakuan $\mathrm{C}$ (Tepung dedak) dan $\mathrm{A}$ (Ampas tahu) diduga pada perlakuan $\mathrm{C}$ (Tepung dedak) kelebihan kandungan energi sehingga cacing lambat 
berkembang biak. Kualitas nutrisi pada pakan ditentukan oleh tingkat kecernaan dan komposisi kimiawinya Subandiyono dan Astuti (2010) dalam Kusumorini et al.,(2017). Sebaiknya protein dan energi yang terkandung didalam pakan harus seimbang karena kelebihan energi dan kekurangan energi juga dapat menurunkan laju pertumbuhan dan menghambat perkembangbiakan Cacing Sutera (Tubifex sp). Sedangkan pada perlakuan A didapati jumlah populasi cacing yang paling rendah hal tersebut diduga adanya kandungan asam cuka/asetat yang merupakan senyawa kimia yang terdapat pada ampas tahu yang dapat menghambat proses perkembangbiakan cacing sehingga populasi cacing tidak berkembang pesat dengan dicirikan hidupnya berkelompok dibawah saluran inlet membentuk seperti peta dan tidak merata. Selain itu penurunan jumlah cacing sutera (Tubifex $s p$ ) diduga karena kegagalan cacing muda dalam mempertahankan kelangsungan hidup Safrudin et al.,(2005).

\section{KESIMPULAN}

1. Komposisi media pemeliharaan yang terbaik pada perlakuan B (Tepung udang) dibanding dengan perlakuan $\mathrm{C}$ (Tepung dedak) dan A (Ampas tahu).

2. Biomassa Cacing Sutera (Tubifex $s p$ ) tertinggi pada perlakuan $\mathrm{B}$ (Tepung udang) dengan nilai 503,99 gram sedangkan perlakuan $\mathrm{C}$ (Tepung dedak) berkisar 414,45 gram dan perlakuan A (Ampas tahu) berkisar 309,41 gram.

\section{DAFTAR PUSTAKA}

Agustinus, F. 2016. Pengaruh Media Budidaya yang Berbeda Terhadap Kepadatan Populasi Cacing Tubifex (Tubifex sp.). Jurnal Ilmu Hewani Tropika $5(1)=45-49$.

Adlan, M. A. 2014. Pertumbuhan Biomassa Cacing Sutera (Tubifek sp.) Pada Media Kombinasi Pupuk Kotoran Ayam dan Ampas Tahu. [Skripsi] Fakultas Peternakan. Universitas Gadjah Mada. Yogyakarta.

Ahmad, F. 2008. Analisis Kadar aunsur Hara Carbon Organik dan Nitrogen Didalam Tanah Perkebunan Kelapa Sawit Bengkalis Riau. Skripsi. Program Studi Diploma 3 Kimia Analis. Universitas Sumatera Utara Medan.

Ahmad, 2016. Pengaruh Padat Tebar dan Pemberian Pakan Ampas Tahu Dengan Dosis Berbeda Terhadap Pertumbuhan Biomassa, Pertambahan Panjang dan Populasi Cacing Sutera (Tubifex sp) . Skripsi. Fakultas Perikanan dan Kelautan Universitas Riau, Pekanbaru.Hlm.

Afrianto, E. Dan Liviawaty, E. 2005 Pakan Ikan. Penerbit Kanasius. Yogyakarta

Bintaryanto, B.W, Tufikurohma, 2013. Pemanfaatan Campuran Limbah Padat (Sludge) Pabrik kertas dan Kompos Sebagai Media Kultur Cacing Sutera (Tubifex sp). UNESA Jurnal of Chemistry 2 (1) : $7 \mathrm{hlm}$

Chumaidi dan Suprapto.1986. Populasi Tubifex sp. di Dalam Media Campuran Kotoran Ayam dan Lumpur Kolam. Bulletin Penelitian Perikanan Darat. Depok 5 (2): 6 11

Effendi, M. 2013. Beternek Cacing Sutera Cara Modern. Penebar Sawadaya Jakarta. 
Effendi, M. 2015. Beternak Cacing Sutera Cara Modern. Penebar

Swadaya Jakarta.

Effendi, M dan Tiyoso,A. 2017. Panen Cacing Sutera. PT Agromedia Pustaka Jakarta.

Findi, S. 2011. Pengaruh tingkat pemberian kotoran sapi terhadap pertumbuhan biomassa cacing sutra Tubificidae [Skripsi]. Bogor : Institut Pertanian Bogor.

Febrianti, D. 2004. Pengaruh Pemupukan Harian Dengan Kotoran Ayam Terhadap Pertumbuhan Populasi dan Biomassa Cacing Sutera (Limnodrilulus). Skripsi. Fakultas Perikanan dan Kelautan. Institut Pertanian Bogor.

Games Kwancai dan Gomes Arturo.1995. Prosedur Statistik untuk Penelitian Pertanian. Jakarta Universitas Indonesia (UI Press). $698 \mathrm{~h}$

Hadiroseyani, Y. D. Nurjanah, Wahjuningrum. 2007. Kelimpahan Bakteri Dalam Budidaya Cacing Limnodrilus sp. yang dipupuk kotoran ayam hasil fermentasi. Jurnal Akuakultur Indonesia. 6 (1) : $79-87$.

Kusumorini,A.Cahyanto.T, Utami L.D. 2017. Pengaruh Pemberian Fermentasi Kotoran Ayam Terhadap populasi dan Biomassa cacing (Tubifex Tubifex).Jurnal. X (1) : $1979-8911$.

Marian Mp dan TJ Padian, 1984. Culture and Harvesting Technique for Tubifex. Aquaculture, 42: $303-$ 315.

Rusdi, U.D. 1992. Fermentasi Konsentrat Campuran Bungkil Biji Kapuk dan Onggok Serta Implikasi Efeknya Terhadap Pertumbuhan Ayam Broiler. Disertasi Universitas Padjajaran Bandung.
Shafrudin, D. Efriyanti, W. dan Widanarni. 2005. Pemanfaatan Ulang Limbah Organik Dari Substrak Tubifex sp. di Alam. Jurnal Akuakultur Indonesia, 4(2) = 97-102.

Syahendra, F. Hutabarat, J. Dan Herawati V. 2016. Pengaruh Pengkayaan Bekatul dan Ampas Tahu Dengan Kotoran Burung Puyuh yang Di Fermentasi Dengan Ekstrak Limbah Sayur Terhadap Biomassa dan Kandungan Nutrisi Cacing Sutera (Tubifex sp.). Jurnal of Aquaculture Management and Technology $5(1)=35-44$

Suharyadi, 2012. Studi Pertumbuhan dan Produksi Cacing Sutera (Tubifex sp) Dengan Pupuk Yang Berbeda Dalam Sistem Resirkulasi (Tesis). Program Pascasarjana Program Studi kelautan Bidang Minat Manajemen Perikanan. Univesitas Terbuka. Jakarta $84 \mathrm{hlm}$. Weatherley A H. 1972. Growth and Ecology of Fish Populations. Academic Press. London. New York. 293 p.

Withley L.S. 1968. The resittance of Tubificids worms to three common pollutans. Hidrobiologi. 32 : 193 205.

Yuherman, 1987. Pengaruh Dosis Penambahan Pupuk Pada Hari Kesepuluh Setelah Inokulasi Terhadap Pertumbuhan Populasi Tubifex sp. Skripsi. Fakultas Perikanan. Institut Pertanian Bogor, Bogor. 